\title{
Tissue renin-angiotensin system: its expression, localization, regulation and potential role in the pancreas
}

\section{P S Leung and P O Carlsson ${ }^{1}$}

Department of Physiology, Faculty of Medicine, The Chinese University of Hong Kong, Shatin, NT, Hong Kong

${ }^{1}$ Department of Medical Cell Biology, Biomedical Center, Uppsala University, Uppsala, Sweden

(Requests for offprints should be addressed to P S Leung, Department of Physiology, Faculty of Medicine, The Chinese University of Hong Kong, Shatin, NT, Hong Kong;

Email: psleung@cuhk.edu.hk)

\begin{abstract}
The classical concept of the renin-angiotensin system (RAS) is that of a blood-borne cascade, whose final and bioactive product, angiotensin II, plays an important endocrine role in the maintenance of blood pressure and electrolyte as well as fluid balance. In addition to this circulating RAS, there are an increasing number of studies to suggest the existence of a local angiotensin-generating system in several tissues. The so-called tissue RAS can act locally as a paracrine and/or autocrine factor in meeting specific needs for individual tissues and it can operate, in whole or in part, independently of the circulating counterpart. Recent studies on the expression and localization of key RAS components, particularly angiotensinogen and renin, have provided solid evidence for the existence of an intrinsic, angiotensin-generating system in the pancreas. The
\end{abstract}

tissue RAS has a potential role in finely regulating exocrine and endocrine functions of the pancreas such as ductal anion secretion and islet hormonal secretion. Some of these effects may be exerted via the markedly vasoconstrictive effects of RAS. Of particular interest in this context are the recent epidemiological data showing that administration of angiotensin-converting enzyme inhibitors appears to be protective against the development of diabetes in hypertensive patients. Moreover, the upregulation of pancreatic RAS has been shown to occur during chronic hypoxia. The significance of changes in pancreatic RAS could have a potential role in acute pancreatitis, islet transplantation and in different shock states, by causing a further decrease of blood perfusion in the pancreas.

Fournal of Molecular Endocrinology (2001) 26, 155-164

\section{INTRODUCTION}

Classically, the renin-angiotensin system (RAS) has been considered a hormonal circulating system. The so-called systemic or circulating RAS plays a crucial role in the maintenance of blood pressure. This is mediated through its constrictive actions on vascular smooth muscle and by its influence on aldosterone secretion from the adrenal cortex, electrolyte transport in kidney tubules (Page \& Bumpus 1974, Peach 1977, Reid et al. 1978), and on thirst as well as sodium appetite in the brain (Fitzsimons 1998). In addition to its actions on the cardiovascular, renal and nervous systems, RAS has many other actions on peripheral target tissues, from which it can elicit various specific responses for individual tissue functions (Dzau \& Pratt 1986). For example, RAS has been previously demonstrated to play an important role in the regulation of various reproductive functions (Ganong 1995, Leung et al. 1999b, Speth et al. 1999).

There is a scarcity of information presently available on RAS in the pancreas and its potential roles in the regulation of pancreatic exocrine/ endocrine functions are largely undefined. Of interest in this context is the notion of the role of angiotensinogen in essential hypertension, as described recently (Hata 1995). A strong association 


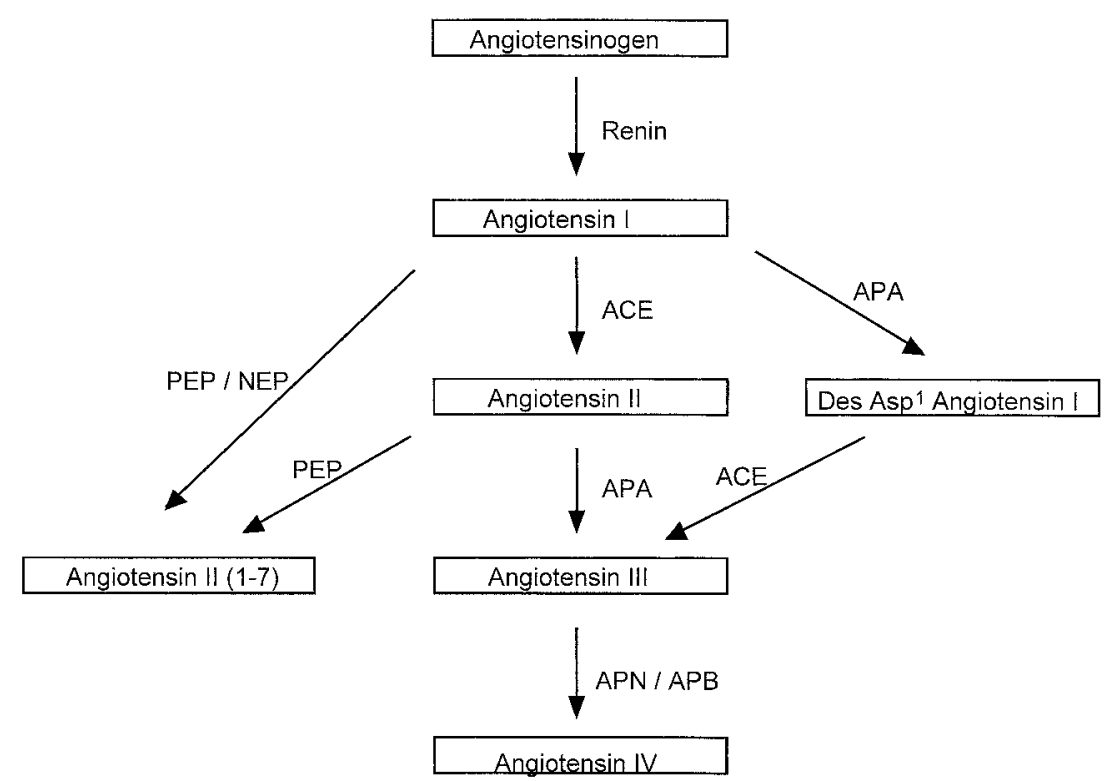

FIGURE 1. Schematic drawing of processing pathways for RAS. APA, aminopeptidase A; APN, aminopeptidase N; APB, aminopeptidase B; PEP, prolylendopeptidase; NEP, neutral endopeptidase.

seems to exist between essential hypertension and diabetes mellitus (Stern 1995). The beneficial effects of angiotensin-converting enzyme (ACE) inhibition for pancreatic insulin secretion in many hypertensive patients (Pollare et al. 1989, Santoro et al. 1992), therefore, underline the importance of our understanding of the physiological and pathophysiological roles of tissue RAS in the pancreas.

Future research on RAS in the pancreas could provide an insight into several pancreatic diseases including inflammatory diseases, diabetes mellitus, cystic fibrosis and cancer. It could also shed new light on our understanding of hypertension and pancreatic islet transplant physiology. This review will focus on the current knowledge of the expression, localization and regulation of a tissue RAS in the pancreas. In addition, the potential physiological and pathophysiological consequences of a tissue RAS in the exocrine and endocrine pancreas will be discussed.

\section{CIRCULATING AND TISSUE RAS}

The physiologically active endocrine product of the circulating RAS, angiotensin II, is spliced from its liver-derived precursor angiotensinogen (Menard et al. 1993) by a sequential action of two critical enzymes (Fig. 1). The first enzyme, renin, is secreted from juxtaglomerular cells in the kidney (Hackenthal et al. 1990). Renin splits a specific leucine-leucine peptide bond in circulating angiotensinogen, resulting in the formation of the decapeptide angiotensin I. Angiotensin I is then carried via the blood to the lungs, where the second enzyme, ACE, removes two amino acids from the carboxy terminus of angiotensin I to form the active octapeptide angiotensin II. ACE is a membranebound enzyme anchored on the endothelium of many vascular beds with the highest concentrations found on the vascular epithelium of the lung (Caldwell et al. 1976). Other enzymes may act on angiotensin I or angiotensin II to yield various active peptide fragments including angiotensin III, angiotensin II(1-7) and angiotensin IV (Fig. 1). Circulating angiotensin II and these bioactive peptide fragments are dispersed to the target tissues of the body, where they exert a multiplicity of physiological functions via their interactions with specific angiotensin receptors, such as $\mathrm{AT}_{1 \mathrm{a}}, \mathrm{AT}_{1 \mathrm{~b}}$, $\mathrm{AT}_{2}$ and $\mathrm{AT}_{4}$ (Matsusaka \& Ichikawa 1997, De Gasparo et al. 2000).

Recently, the focus has shifted from an endocrine role for RAS to an autocrine/paracrine role in specific tissue functions, such as tissue growth and differentiation. The localization and expression of key RAS components, notably angiotensinogen and renin, which are mandatory for the presence of a tissue RAS, have been reported in a range of tissues (Campbell \& Habener 1986, Deschepper et al. 1986, Dzau et al. 1987). The expression of local RAS components in tissues such as the brain, heart, 
kidneys, adrenals and gonads has led to the proposition that these components may either potentiate systemic functions, or have entirely separate activities meeting the specific needs of these individual tissues (Campbell 1987, Dzau 1989, Phillips et al. 1993). There is accumulating evidence that changes in tissue/organ-specific RAS may be associated with the pathophysiology of the respective tissue/organ functions. This gives rise to the possibility that drugs acting on tissue RAS might ameliorate some of these disorders. In fact, a recent study has suggested functional consequences of the action of drugs on tissue RAS (Zimmerman \& Dunham 1997).

\section{EVIDENCE FOR THE EXISTENCE OF A TISSUE RAS AND ITS EXPRESSION AND LOCALIZATION IN THE PANCREAS}

The presence of angiotensin II, angiotensinogen protein and angiotensinogen mRNA have been documented in the dog pancreas (Chappell et al. 1991). Moderately high quantities of angiotensin II $(524 \pm 74 \mathrm{fmol} / \mathrm{g}$ tissue), angiotensin III (221 \pm $54 \mathrm{fmol} / \mathrm{g}$ tissue) and angiotensin II(1-7) levels $(156 \pm \mathrm{fmol} / \mathrm{g}$ tissue) were found. The concentrations of these peptides were several times higher than those measured in blood, indicating that local generation of angiotensin II may occur in the canine pancreas. The notion for the existence of a tissue RAS in the rat pancreas has been consolidated based on the expression and localization of angiotensinogen, the mandatory component for an intrinsic RAS (Leung et al. 1999a). However, the concentration of angiotensinogen in the pancreas of both rats and dogs was low, and constituted only approximately $2 \cdot 5 \%$ of circulating angiotensinogen concentrations (Chappell et al. 1991, Leung et al. 1999a). Using the Northern blot technique, angiotensinogen mRNA was not detected in the rat pancreas (Campbell \& Habener 1986). This discrepancy may be explained by the reduced sensitivity of Northern blots, in combination with the possible degradation of angiotensinogen mRNA during its extraction from the RNAase-rich pancreas. In addition to angiotensinogen, renin $\mathrm{mRNA}$ has also been found to be expressed in the rat pancreas (Leung et al. 1999a), indicating that, at least in this species, a renin-dependent RAS is operative. However, further investigations are needed to confirm the renin-dependence in the angiotensin II-generating system of the rat pancreas. In the canine pancreas, neither angiotensin I nor renin activity has been detected (Chappell et al. 1991), suggesting that this pancreatic RAS may be renin-independent. Multiple biosynthetic pathways of locally generating reninindependent RAS system have been proposed (Dzau 1989). Kallikrein, an enzyme capable of forming angiotensin II directly from its precursor angiotensinogen, has been reported to be present in the dog pancreas (Hojima et al. 1977).

Angiotensin II receptor subtypes have also been localized and characterized autoradiographically and pharmacologically in the pancreas. Preferentially, the $\mathrm{AT}_{2}$ subtype was found to be expressed in different cell types of the pancreatic tissue in dogs (Chappell et al. 1991, 1992, 1995). More recently, specific binding sites for angiotensin II have been detected in both the endocrine and exocrine portions of the rat pancreas (Ghiani \& Masini 1995). Interestingly, these angiotensin II-binding sites were subject to modulation by sodium loading and depletion. Our recent immunohistochemical studies have shown that both the $\mathrm{AT}_{1}$ and $\mathrm{AT}_{2}$ receptor subtypes (Leung et al. 1997a) as well as angiotensin II (Leung et al. 1998) are localized to various rodent pancreatic cell types, but predominantly to the epithelia of pancreatic ducts and endothelia of blood vessels. Immunoreactivities for the $\mathrm{AT}_{1}$ and $\mathrm{AT}_{2}$ receptor subtypes as well as for angiotensin II are also found in the rodent acinar cells, although the immunoreactivity is weaker when compared with that observed in the pancreatic ducts and vasculature. In contrast, a diffuse distribution of both angiotensin II receptor subtypes has been observed throughout the exocrine and endocrine portions of the canine pancreas, i.e. in the acinar cells, duct cells and vascular elements, as well as in the pancreatic islets (Chappell et al. 1991, 1992). The discrepancy between the results in the rodent and those obtained in the canine could be due to species difference, or alternatively to the limitations of different techniques employed. A cellular localization of RAS components to the pancreatic islets has recently been reported in the human pancreas. In that study, $\mathrm{AT}_{1}$ receptors and (pro)renin were localized not only to the exocrine part but also to the beta-cells of the endocrine part of the human pancreas (Tahmasebi et al. 1999).

Taken together, all these data support the existence of an intrinsic, angiotensin-generating system in the pancreas, which may be of importance in the regulation of pancreatic exocrine and endocrine functions.

\section{REGULATION OF PANCREATIC TISSUE RAS BY CHRONIC HYPOXIA}

The regulation of tissue RAS is subject to a number of factors such as hormones, ions and stress 
(Phillips et al. 1993). Hypoxic stress is known to be one such factor which may lead to changes of tissue RAS expression in, for example, the kidney (Neylon et al. 1996), the lung (Morrell et al. 1995), the carotid body (Leung et al. 2000b), the epididymis (Leung et al. 2001) and the heart (Morrell et al. 1997). These data suggest that tissue RAS is differentially affected by hypoxia and is intimately involved in both the physiology and pathophysiology of the respective tissues.

We have recently demonstrated the activation of tissue RAS by a rat model of chronic hypoxia in the pancreas (Chan et al. 2000). Chronic hypoxia elicited a marked increase in mRNA and protein expression of angiotensinogen (Fig. 2). Moreover, there was a selective upregulation of mRNAs for the $\mathrm{AT}_{1 \mathrm{~b}}$ and $\mathrm{AT}_{2}$ receptor subtypes by chronic hypoxia. Such differential changes of pancreatic RAS components may be responsible for finely regulating the physiology and adaptation of the pancreas during chronic hypoxia, but could also trigger hypoxia-induced pancreatic injury such as acute pancreatitis (vide infra).

\section{CURRENT EVIDENCE FOR A PHYSIOLOGICAL ROLE FOR TISSUE RAS IN THE PANCREAS}

All these combined data suggest the presence of a pancreatic tissue RAS, which may have physiological effects via a paracrine/autocrine fashion in the exocrine and endocrine pancreas, e.g. in the regulation of pancreatic microcirculation, ductal anion secretion and islet hormonal secretion. In fact, recent results have demonstrated that such local RAS may influence ductal anion secretion in the rat exocrine pancreas (Chan et al. 1997, Cheng et al. 1999). In those studies, the presence of $\mathrm{AT}_{1}$ receptors was described in a cystic fibrosis human pancreatic duct cell line, CFPAC-1, and the influence of electrogenic ion transport was demonstrated. The data indicate that angiotensin II may be of importance for normal exocrine function of the pancreas, particularly for the regulation of pancreatic ductal $\mathrm{HCO}_{3}^{-}$secretion via activation of apical $\mathrm{Cl}^{-}$channels. Similar effects of angiotensin II on electrogenic ion transport have also been observed in other forms of secretory epithelia, including those from the trachea (Norris et al. 1991), intestine (Cox et al. 1987) and epididymis (Leung et al. 1997b).

It has previously been shown that angiotensin II receptors influence prostaglandin synthesis (Jaiswal et al. 1990, 1991), which in turn may modulate the secretion of insulin and glucagon from the
(A)

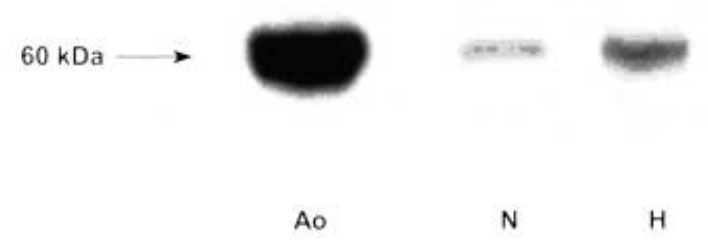

(B)

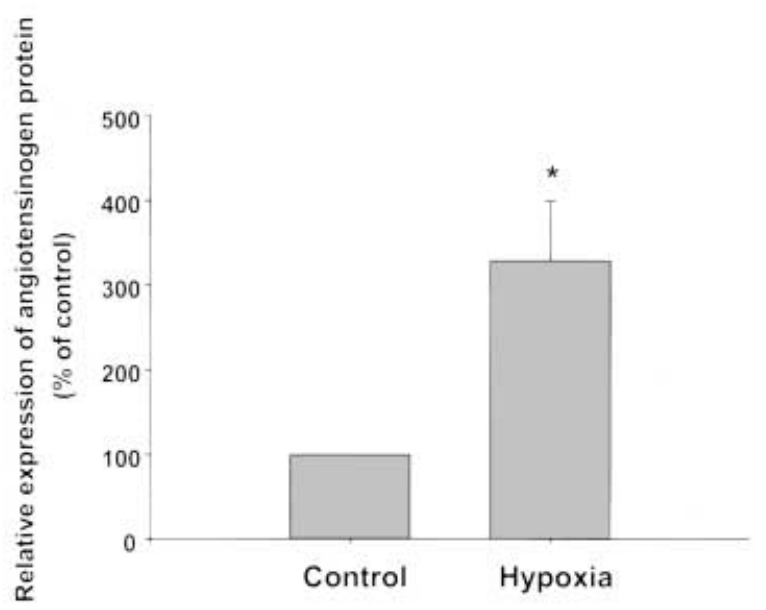

FIGURE 2. (A) Western blot analysis of angiotensinogen protein expression by chronic hypoxia in rat pancreas. Lane Ao shows plasma angiotensinogen purified from nephrectomized rat. A major band of about $60 \mathrm{kDa}$ was detected. Lane $\mathrm{N}$ shows the expression by normoxic pancreas $(10 \mu \mathrm{g}$ protein) and lane $\mathrm{H}$ shows the expression by chronic hypoxic pancreas (10 $\mu \mathrm{g}$ protein). In this immunoblotting, the primary antibody is a rabbit anti-rat angiotensinogen serum (Thomas \& Sernia 1988) at 1:5000 dilution and the secondary antibody is a peroxidase-labeled anti-rabbit $\operatorname{IgG}$ at 1:500 dilution. (B) Relative expression of angiotensinogen protein in hypoxic pancreas compared with that of normoxic pancreas. The data are expressed as means \pm s.E.M. ( $n=5$ /group). Reproduced from Chan et al. (2000) with permission from Molecular and Cellular Endocrinology.

endocrine pancreas (Kelly \& Laychock 1981). However, no effect of angiotensin II on insulin or glucagon release has been seen in experiments with isolated islets in vitro (Dunning et al. 1984). In a study where enalaprilate, an inhibitor of ACE, and saralasin, a non-selective angiotensin II receptor antagonist, were administered in vivo to rats, an increase in whole pancreatic blood flow, but 
preferentially in islet blood flow, was discerned (Carlsson et al. 1998a). This finding suggests that islet microvessels produce higher concentrations of angiotensin II than those in the exocrine pancreas, and therefore may be more sensitive to ACE or angiotensin II receptor inhibition. Furthermore, islet blood flow seems to be suppressed by this locally produced angiotensin II during normal conditions. In view of the marked vasoactive effects of RAS, the influence on islet function secondary to angiotensin II-induced vasoconstriction was evaluated by measuring insulin concentrations in the effluents from isolated perfused rat pancreata (Carlsson et al. 1998a). In these preparations, addition of angiotensin II to the perfusion medium induced a marked vasoconstriction, which delayed the first phase of insulin release in response to glucose (Fig. 3). This suggests the crucial role of an intact islet blood perfusion for maintenance of an adequate insulin release. Interestingly, i.v. infusion of angiotensin II in a pressor dose $(5 \cdot 0 \mathrm{ng}$ angiotensin II $/ \mathrm{kg}$ per min) in humans suppressed both basal and pulsatile insulin secretion (Fliser et al. 1997). A subpressor dose of angiotensin II ( $1.0 \mathrm{ng} / \mathrm{kg}$ per min) could also suppress insulin secretion. Moreover, the insulinemic response was significantly lower and glucose concentration markedly higher after an oral glucose load when angiotensin II was infused compared with placebo. No study in man has been conducted regarding the influence of angiotensin II on islet blood flow. Vasoconstriction in the islets may nevertheless be regarded as the most likely mechanism for these findings, especially since a number of studies have failed to identify angiotensin II receptors on pancreatic beta-cells.

\section{POTENTIAL PATHOPHYSIOLOGICAL ROLES FOR A TISSUE RAS IN THE PANCREAS}

The etiology of acute pancreatitis has been considered to be multifactorial (Whitcomb 1999), although difference in the triggering mechanisms ends up with the same common pathway. This is the autodigestion of pancreatic tissue by the premature activation of proenzymes prior to their release into the duodenum (Wedgewood \& Reber 1986). Some of the crucial factors may include activation of proteolytic enzymes, lipase, kinins and other vasoactive peptides such as angiotensin II (Agarwal \& Pitchumoni 1993, Lembeck \& Griesbacher 1996). In fact, it was previously reported that the plasma renin was significantly activated in acute pancreatitis, suggesting a role for RAS in the development of pancreatitis (Greenstein et al. 1987, Pitchumoni et al. 1988).
It has previously been reported that hypoxia could result in the decrease of regional blood flow to several tissues including the pancreas, which may enhance tissue inflammation and injury (Kuwahira et al. 1993). A vicious cycle of pancreatic microcirculatory changes such as vasoconstriction, capillary stasis, decreased oxygen tension and progressive ischemia has been shown to occur in the course of acute pancreatitis (Knoefel et al. 1994). A common etiological factor for pancreatitis is alcohol abuse. Interestingly, alcohol has been suggested to induce hypoxia in the pancreas, which could provide a mechanism for the development of pancreatic injury in this case (Foitzik et al. 1995). In view of the upregulation of pancreatic RAS by hypoxic stress and the marked vasoconstrictive effect of this system on pancreatic blood flow (vide supra), the role of RAS in acute pancreatitis may be worthy of consideration.

In a rat model of experimental pancreatitis, markedly increased expression of mRNAs for angiotensinogen was observed (Fig. 4). The expression of the $\mathrm{AT}_{2}$ receptor was also markedly augmented during this condition (Leung et al. $2000 a$ ). The functional role for $\mathrm{AT}_{2}$ receptors in many tissues, e.g. in the pancreas, remains unsettled. In addition, a significant increase in the mRNA expression for the $\mathrm{AT}_{1 \mathrm{a}}$ subtype, but not for the $\mathrm{AT}_{1 \mathrm{~b}}$ subtype, was seen during pancreatitis. It appears that subtype-specific activation of $\mathrm{AT}_{1}$ receptor could play a role in the pathophysiology of acute pancreatitis. However, species differences should be taken into consideration, particularly the fact that such subtypes have not been described in humans. On the other hand, the reasons for and the implications of an increased expression of subtype $\mathrm{AT}_{1 \mathrm{a}}$ during acute pancreatitis (Leung et al. 2000a) and of subtype $\mathrm{AT}_{1 \mathrm{~b}}$ during chronic hypoxia (Chan et al. 2000) remain to be elucidated.

There are indications that activation of the pancreatic RAS occurs during exposure to other forms of stress, such as cardiogenic (Reilly et al. 1997), septic (Oldner et al. 1999) or trauma (Kincaid et al. 1998) shocks. In cardiogenic shock, a selective angiotensin II-mediated pancreatic vasoconstriction is seen that causes severe pancreatic ischemia/hypoxia (Reilly et al. 1997). In the two latter conditions, splanchnic blood perfusion is markedly improved following the treatment of angiotensin II receptor antagonism (Kincaid et al. 1998, Oldner et al. 1999).

Little information exists on pancreatic RAS in pancreatic cancer. An indication of a potential role is that ACE inhibitors decrease mitosis frequency and influence gene expression in pancreatic cancer cells (Reddy et al. 1995). Angiotensinogen gene expression has also been demonstrated in a cell line 

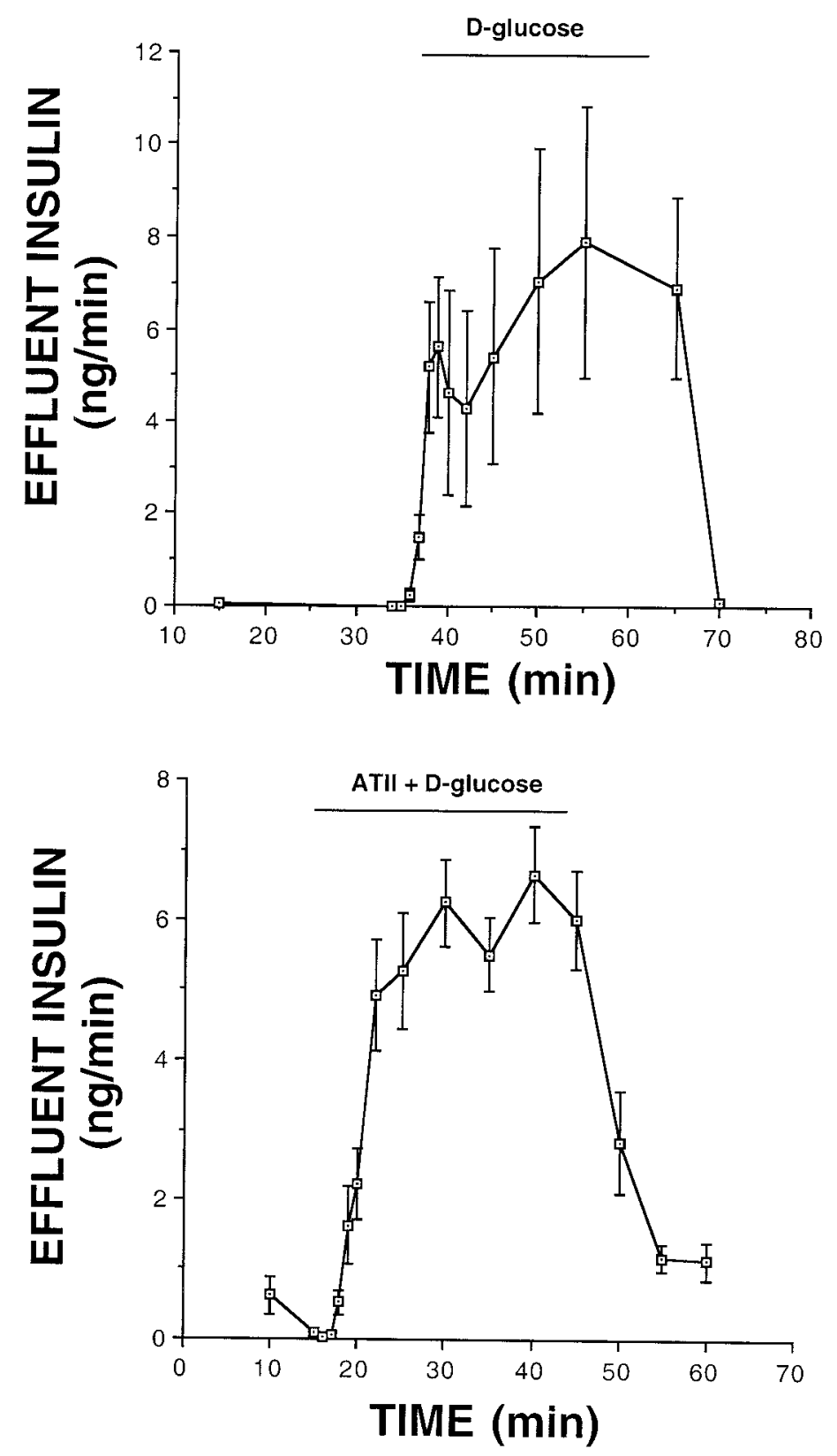

FIGURE 3. Insulin concentrations in effluent medium collected from perfused pancreata of male Sprague-Dawley rats. The upper panel shows insulin secretion in response to a $30 \mathrm{~min}$ period with $16.7 \mathrm{mmol} / \mathrm{l} \mathrm{D}$-glucose (bar) added to the perfusion medium. The lower panel shows insulin secretion in response to a $30 \mathrm{~min}$ period with $16.7 \mathrm{mmol} / \mathrm{l} \mathrm{D}$-glucose $+10 \mathrm{ng} / \mathrm{ml}$ angiotensin II (bar). Values represent means \pm s.E.M. for six or seven experiments. Reproduced from Carlsson et al. (1998a) with permission from Diabetologia. 


\section{(A)}

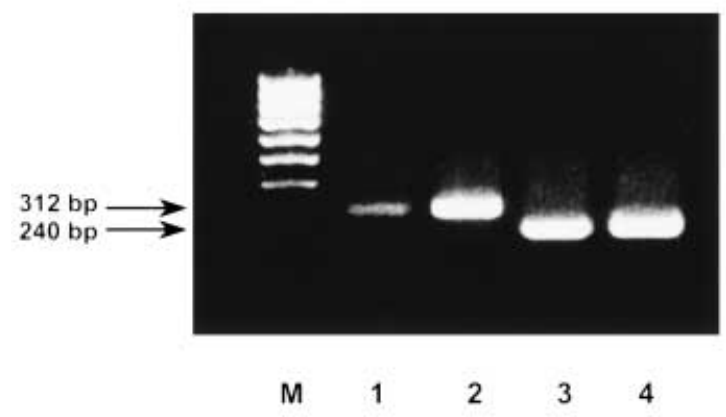

(B)

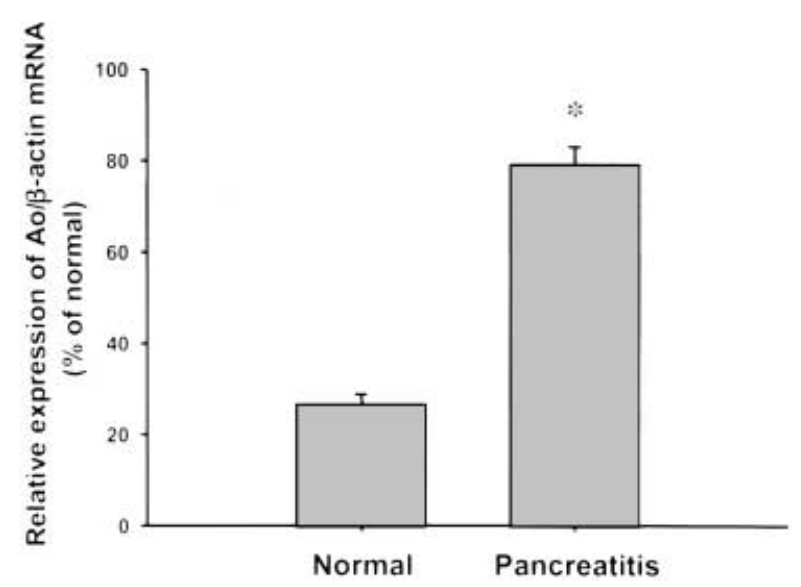

FIGURE 4. (A) RT-PCR analysis of angiotensinogen mRNA in rat pancreatitis. Lane M, DNA marker (X174 RF/HaeIII fragments); lane 1, angiotensinogen expression in normal rats; lane 2, angiotensinogen expression in pancreatitis rats; lane $3, \beta$-actin expression in normal rats; lane $4, \beta$-actin expression in pancreatitis rats. The arrows indicate the expected size of amplified products from angiotensinogen $(312 \mathrm{bp})$ and $\beta$-actin (240 bp). (B) The relative expression of angiotensinogen/ $\beta$-actin mRNA. The data are expressed as means \pm s.E.M. ( $n=5$ /group). Reproduced from Leung et al. (2000a) with permission from Molecular and Cellular Endocrinology.

derived from a pancreatic endocrine tumor in the rat (Brasier et al. 1986). The significance of this latter finding remains to be determined.

A strong linkage seems to exist between type 2 diabetes and essential hypertension (National High Blood Pressure Education Program Working Group 1994, Stern 1995). It has therefore been hypothesized that some factor(s) common to hypertension and diabetes may underlie the strong association between these diseases. Peripheral insulin resistance is commonly found in patients with essential hypertension and type 2 diabetes (Ferrannini et al.
1987). However, it seems that type 2 diabetes does not develop as long as the pancreatic beta-cells can secrete sufficient quantities of insulin to maintain a normal glucose homeostasis (Hellerstrom 1984). Interestingly, several studies in hypertensive patients receiving long-term treatment with ACE inhibitors have described an increased first phase insulin peak in response to i.v. glucose administration (Pollare et al. 1989, Haenni et al. 1994) or oral glucose (Santoro et al. 1992). The mechanism for this is unknown, since angiotensin II receptors have not been described on beta-cells. In view of the profound effects of angiotensin II on islet blood flow, it may be speculated that hyperactivity of the angiotensin system in islet vasculature can impair insulin release (cf. Carlsson et al. 1998a). Indeed, increased ACE concentrations occur in the mesenteric vasculature under the diabetic state, at least in animals (Jandeleit et al. 1992). An increased vasopressor responsiveness to angiotensin II in diabetic patients has also been observed (Christlieb et al. 1976, Drury et al. 1984). In addition, changes in vascular ACE seem to occur in various models of hypertension (Jandeleit et al. 1991). The influence of ACE inhibition on diabetes incidence has been evaluated in clinical trials. When patients at high risk of cardiovascular events, e.g. due to hypertension, were treated with the ACE inhibitor ramipril, a marked reduction in the incidence of diabetes was observed (Heart Outcomes Prevention Evaluation Study 2000). Similar findings were obtained in the Captopril Prevention Project randomized trial (Hansson et al. 1999). In view of these combined findings, it may be of importance to investigate more closely the role of the islet RAS in human diabetes and hypertension, especially with regard to tentative circulatory effects.

In a recent study, infusion of angiotensin $\mathrm{II}$, in a dose that caused no changes in islet blood flow or vascular conductance in endogenous pancreatic islets, caused a marked decrease in both blood flow and vascular conductance in transplanted rat islets (Olsson et al. 2000). These data therefore suggest that the vascular response to angiotensin II in islet transplants is augmented compared with endogenous islets. Interestingly, a chronically marked decrease in graft tissue oxygen tension is seen after transplantation of pancreatic islets (Carlsson et al. 1998c, 2000, 2001). Whether upregulation of RAS occurs secondarily to low oxygen tension levels in the grafted islets remains to be determined. In either case, an increased sensitivity to RAS components may be deleterious for islet graft function. This could be by further reducing islet transplant blood perfusion (cf. Carlsson et al. 1998b,c, 2000, 2001), or by inducing the generation of free radicals (Griendling 
et al. 1994, Ushio-Fukai et al. 1998, Warnholtz et al. 1999) harmful to the scavenger-deficient islets.

\section{CONCLUSIONS}

Recent studies on the expression and localization of key RAS components, particularly angiotensinogen and renin, have provided solid evidence for the existence of an intrinsic, angiotensin-generating system in the pancreas. This tissue RAS may play a potential role in regulating exocrine and endocrine functions of the pancreas such as ductal anion secretion and islet hormonal secretion. Such pancreatic RAS is subjected to the regulation of, for example, chronic hypoxia, and is affected during several other conditions, e.g. acute pancreatitis and different forms of shock. The significance of tissue RAS in the pancreas and its regulation by chronic hypoxia and other factors could be of potential importance in the physiology and pathophysiology of the pancreas. The target for the pancreatic RAS could provide an insight into several pancreatic diseases, including acute pancreatitis, pancreatic cancer, diabetes mellitus and cystic fibrosis. The pancreatic RAS could also have implications for pancreatic islet transplantation.

\section{ACKNOWLEDGEMENTS}

The authors wish to thank the Research Grants Council of Hong Kong (CUHK 4075/00M), the Research Committee Funding and the Mainline Research Scheme from the Chinese University of Hong Kong (MR00/008), the Swedish Medical Research Council (17X-109), the Juvenile Diabetes Foundation and the Wallenberg Foundation, the Swedish Diabetes Association, Svenska Barndiabetesfonden, the Magnus Bergvall Foundation and the Thuring Foundation.

\section{REFERENCES}

Agarwal N \& Pitchumoni CS 1993 Acute pancreatitis: a multisystem disease. Gastroenterologist 1 115-128.

Brasier AR, Philippe J, Campbell DJ \& Habener JF 1986 Novel expression of the angiotensinogen gene in a rat pancreatic islet cell line: transcriptional regulation by glucocorticoids. Fournal of Biological Chemistry 261 16148-16154.

Caldwell PRB, Seegal BC, Hsu KC, Das M \& Soffer RL 1976 Angiotensin-converting enzyme: vascular endothelial localization. Science 191 1050-1051.

Campbell DJ 1987 Circulating and tissue angiotensin systems. Fournal of Clinical Investigation 79 1-6.
Campbell DJ \& Habener J 1986 Angiotensinogen gene is expressed and differentially regulated in multiple tissues of the rat. Fournal of Clinical Investigation 78 31-39.

Carlsson PO, Berne C \& Jansson L 1998 a Angiotensin II and the endocrine pancreas: effects on islet blood flow and insulin secretion in rats. Diabetologia 41 127-133.

Carlsson PO, Jansson L, Andersson A \& Kallskog Ö $1998 b$ Capillary blood pressure in syngeneic rat islets transplanted under the renal capsule is similar to that of the implantation organ. Diabetes 47 1586-1593.

Carlsson PO, Liss P, Andersson A \& Jansson L $1998 c$ Measurements of oxygen tension in native and transplanted rat pancreatic islets. Diabetes 47 1027-1032.

Carlsson PO, Palm F, Andersson A \& Liss P 2000 Chronically decreased oxygen tension in rat pancreatic islets transplanted under the kidney capsule. Transplantation 69 761-766.

Carlsson PO, Palm F, Andersson A \& Liss P 2001 Markedly decreased oxygen tension in transplanted rat pancreatic islets irrespective of the implantation site. Diabetes 50 489-495.

Chan HC, Law SH, Leung PS \& Wong PYD 1997 Angiotensin II receptor type I-regulated anion secretion in cystic fibrosis pancreatic duct cells. Fournal of Membrane Biology 156 241-250.

Chan WP, Fung ML, Nobiling R \& Leung PS 2000 Activation of local renin-angiotensin system by chronic hypoxia. Molecular and Cellular Endocrinology 160 107-114.

Chappell MC, Milsted A, Diz DI, Brosnihan KB \& Ferrario CM 1991 Evidence for an intrinsic angiotensin system in the canine pancreas. Fournal of Hypertension 9 751-759.

Chappell MC, Diz DI \& Jacobsen DW 1992 Pharmacological characterization of angiotensin II binding sites in the canine pancreas. Peptides 13 311-318.

Chappell MC, Jacobsen DW \& Tallant EA 1995 Characterization of angiotensin II receptor subtypes in pancreatic acinar AR42J cells. Peptides 16 741-747.

Cheng HS, So SC, Law SH \& Chan HC 1999 Angiotensin II-mediated signal transduction in cystic fibrosis pancreatic duct cells. Biochimica et Biophysica Acta 1449 254-260.

Christlieb AR, Janka HU, Kraus B, Gleason RE, Icasas-Cabral A \& Aiello LM 1976 Vascular reactivity to angiotensin II and norepinephrine in diabetic subjects. Diabetes 25 268-274.

Cox HM, Cuthbert AW \& Mundey KA 1987 The effect of angiotensin II upon electrogenic ion transport in rat intestinal epithelia. British Fournal of Pharmacology 90 393-401.

De Gasparo M, Catt KJ, Inagami T, Wright JW \& Unger TH 2000 The angiotensin II receptors. Pharmacological Reviews $52415-472$.

Deschepper CF, Mellon SH, Cumin F, Baxter JD \& Ganong WF 1986 Analysis by immunocytochemistry and in situ hybridization of renin and its mRNA in kidney, testis adrenal, and pituitary of the rat. PNAS $837552-7556$.

Drury PL, Smith GM \& Ferris JB 1984 Increased vasopressor responsiveness to angiotensin II in type 1 (insulindependent) diabetic patients without complications. Diabetologia 27 174-179.

Dunning BE, Molt JH \& Fawcett CP 1984 Actions of neurohypophysial peptides on pancreatic hormone release. American Fournal of Physiology 246 E108-E114.

Dzau VJ 1989 Multiple pathways of angiotensin production in the blood vessel wall: evidence, possibilities and hypotheses. Fournal of Hypertension 7 933-936.

Dzau VJ \& Pratt RE 1986 Renin-angiotensin system: biology, physiology and pharmacology. In Handbook of Experimental Cardiology, pp 1631-1661. Eds E Haber, H Morgan, A Katz \& H Fozzard. New York: Raven.

Dzau VJ, Ellison KE, Brody T, Ingelfinger J \& Pratt E 1987 A comparative study of the distribution of renin and 
angiotensinogen messenger ribonucleic acids in rat and mouse tissues. Endocrinology 120 358-364.

Ferrannini E, Buzzigoli G, Bonnadonna R, Griorico MA, Oleggini M \& Graziadei L 1987 Insulin resistance in essential hypertension. New England Fournal of Medicine 317 350-357.

Fitzsimons JT 1998 Angiotensin, thirst and sodium appetite. Physiological Reviews 78 583-686.

Fliser D, Schaefer F, Schmid D, Veldhuis JD \& Ritz E 1997 Angiotensin II affects basal, pulsatile and glucose-stimulated insulin secretion in humans. Hypertension 30 1156-1161.

Foitzik T, Castillo F, Rattner DW, Klar E \& Warshaw AL 1995 Alcohol selectively impairs oxygenation of the pancreas. Archives of Surgery 130 357-361.

Ganong WF 1995 Reproduction and the renin-angiotensin system. Neuroscience and Biobehavioral Reviews 19 241-250.

Ghiani BU \& Masini MA 1995 Angiotensin II binding sites in the rat pancreas and their modulation after sodium loading and depletion. Comparative Biochemistry and Physiology 111A 439-444.

Greenstein RJ, Krakoff LR \& Felton K 1987 Activation of the renin system in acute pancreatitis. American Fournal of Medicine 82 401-404.

Griendling KK, Minieri CA, Ollerenshaw JD \& Alexander RW 1994 Angiotensin II stimulates NADH and NADPH oxidase activity in cultured vascular smooth muscle cells. Circulation Research 74 1141-1148.

Hackenthal E, Paul M, Ganten D \& Taugner R 1990 Morphology, physiology, and molecular biology of renin secretion. Physiological Reviews 70 1067-1116.

Haenni A, Andersson PE, Lind L, Berne C \& Lithell H 1994 Electrolyte changes and metabolic effects of lisinopril/bendrofluazide treatment: Results from a randomised, double-blind study with parallel groups. American Fournal of Hypertension 7 615-622.

Hansson L, Lindholm DH, Niskanen L, Lanke J, Hedner T \& Niklason A 1999 Effects of angiotensin-converting enzyme inhibition compared with conventional therapy on cardiovascular morbidity and mortality in hypertension: the Captopril Prevention Project (CAPP) randomised trial. Lancet 353 611-616.

Hata A 1995 Role of angiotensinogen in the genetics of essential hypertension. Life Sciences 57 2385-2395.

Heart Outcomes Prevention Evaluation Study 2000 Effects of an angiotensin-converting enzyme inhibitors ramipril on cardiovascular events in high-risk patients. New England Fournal of Medicine 342 145-153.

Hellerstrom C 1984 The life story of the pancreatic B cell. Diabetologia 26 393-400.

Hojima Y, Yamashita N, Ochi N, Moriwaki C \& Moriya H 1977 Isolation and properties of dog and rat pancreatic kallikreins. Fournal of Biochemistry 81 599-610.

Jaiswal N, Taillant EA, Diz DI, Khosla MC \& Ferrario CM 1990 Identification of two distinct angiotensin receptors on human astrocytes using an angiotensin receptor antagonist. Hypertension 17 1115-1120.

Jaiswal N, Diz DI, Taillant EA, Kosla MC \& Ferrario CM 1991 Characterization of angiotensin receptors mediating prostaglandin synthesis in C6 glioma cells. American fournal of Physiology 260 R1000-R1006.

Jandeleit K, Jackson B, Perich R, Paxton D \& Johnston CI 1991 Angiotensin-converting enzyme in macro- and microvessels of the rat. Clinical and Experimental Pharmacology and Physiology 18 353-356.

Jandeleit K, Rumble J, Jackson B \& Cooper ME 1992 Mesenteric vascular angiotensin-converting enzyme is increased in experimental diabetes mellitus. Clinical and Experimental Pharmacology and Physiology 19 343-347.
Kelly KL \& Laychock SG 1981 Prostaglandin synthesis and metabolism in isolated pancreatic islets of the rat. Prostaglandins 21 756-769.

Kincaid EH, Miller PR, Meredith JW \& Chang MC 1998 Enalaprilat improves gut perfusion in critically injured patients. Shock 9 79-83.

Knoefel WT, Kollias N, Warshaw AL, Waldner H, Nishioka NS \& Rattner DW 1994 Pancreatic microcirculatory changes in experimental pancreatitis of graded severity in rat. Surgery 116 904-913.

Kuwahira I, Gonzalez NC, Heisler N \& Piipet J 1993 Changes in regional blood-flow distribution and oxygen-supply during hypoxia in conscious rats. Fournal of Applied Physiology $\mathbf{7 4}$ 211-214.

Lembeck F \& Griesbacher T 1996 Pathophysiological and possible physiological roles of kinins in the pancreas. Immunopharmacology 33 336-338.

Leung PS, Chan HC, Fu LXM \& Wong PYD $1997 a$ Localization of angiotensin II receptor subtypes $\mathrm{AT}_{1}$ and $\mathrm{AT}_{2}$ in the pancreas of rodents. Fournal of Endocrinology 153 269-274.

Leung PS, Chan HC, Fu LXM, Zhou WL \& Wong PYD $1997 b$ Angiotensin II receptors, $\mathrm{AT}_{1}$ and $\mathrm{AT}_{2}$ in the rat epididymis: immunocytochemical and electrophysiological studies. Biochimica et Biophysica Acta 1357 65-72.

Leung PS, Chan HC \& Wong PYD 1998 Immunohistochemical localization of angiotensin II in the mouse pancreas. Histochemical fournal 30 21-25.

Leung PS, Chan WP, Wong TP \& Sernia C 1999a Expression and localization of renin-angiotensin system in the rat pancreas. Fournal of Endocrinology 160 13-19.

Leung PS, Wong TP \& Sernia C $1999 b$ Angiotensinogen expression by rat epididymis: evidence for an intrinsic, angiotensin-generating system. Molecular and Cellular Endocrinology 155 115-122.

Leung PS, Chan WP \& Nobiling R 2000a Regulated expression of pancreatic renin-angiotensin system in experimental pancreatitis. Molecular and Cellular Endocrinology 166 121-128.

Leung PS, Lam SY \& Fung ML $2000 b$ Chronic hypoxia upregulates the expression and function of $\mathrm{AT}_{1}$ receptor in rat carotid body. Fournal of Endocrinology 167 517-524.

Leung PS, Fung ML \& Sernia C 2001 Chronic hypoxia induced down-regulation of angiotensinogen expression in the rat epididymis. Regulatory Peptides 96 143-149.

Matsusaka T \& Ichikawa I 1997 Biological functions of angiotensin and its receptors. Annual Review of Physiology 59 395-412.

Menard J, Clauser E, Bouhnik J \& Corvol P 1993 Angiotensinogen: biochemical aspects. In The Renin Angiotensin System, pp 8·1-8·10. Eds JIS Robertson \& MS Nichollas. London: Gower Medical Publishing.

Morrell NW, Atochina EN, Morris KG, Danilov SW \& Stenmark KR 1995 Angiotensin converting enzyme is increased in small pulmonary arteries of rats with hypoxia-induced pulmonary hypertension. Fournal of Clinical Investigation 96 1823-1833.

Morrell NW, Danilov SW, Satyan KB, Morris KG \& Stenmark KR 1997 Right ventricular angiotensin converting enzyme activity and expression is increased during hypoxic pulmonary hypertension. Cardiovascular Research 34 393-403.

National High Blood Pressure Education Program Working Group 1994 The national high blood pressure education program working group report on hypertension in diabetes. Hypertension 23 145-158.

Neylon M, Marshall J \& Johns EJ 1996 The role of the renin-angiotensin system in the renal response to moderate 
hypoxia in the rat. Fournal of Physiology 491 479-488.

Norris B, Gonzalez C, Concha J, Palacios S \& Contreras G 1991 Stimulatory effect of angiotensin II on electrolyte transport in canine tracheal epithelium. General Pharmacology 22 527-531.

Oldner A, Wanecek M, Weitzberg E, Rundgren M, Alving K, Ullman J \& Rudehill A 1999 Angiotensin II receptor antagonism increases gut oxygen delivery but fails to improve intestinal mucosal acidosis in porcine endotoxin shock. Shock 11 127-135.

Olsson R, Jansson L, Andersson A \& Carlsson PO 2000 Local blood flow regulation in transplanted rat pancreatic islets: influence of adenosine, angiotensin II and nitric oxide inhibition. Transplantation 70 280-287.

Page IH \& Bumpus FM 1974 Angiotensins. New York: Springer Verlag.

Peach M 1977 Renin-angiotensin system: biochemistry and mechanism of action. Physiological Reviews 57 313-370.

Phillips MI, Speakman EA \& Kimura B 1993 Levels of angiotensin and molecular biology of the tissue renin-angiotensin system. Regulatory Peptides 43 1-20.

Pitchumoni CS, Agarwal N \& Jain NK 1988 Systemic complications of acute pancreatitis. American Fournal of Gastroenterology 83 597-606.

Pollare T, Lithell H \& Berne C 1989 A comparison of the effects of hydrochlorothiazide and captopril on glucose and lipid metabolism in patients with hypertension. New England Fournal of Medicine 321 868-873.

Reddy MK, Baskaran K \& Molteni A 1995 Inhibitors of angiotensin-converting enzyme modulate mitosis and gene expression in pancreatic cancer cells. Proceedings of the Society for Experimental and Biological Medicine 210 221-226.

Reid IA, Morris BJ \& Ganong WF 1978 The renin-angiotensin system. Annual Review of Physiology 40 377-410.

Reilly PM, Toung TJ, Miyachi M, Schiller HJ \& Bulkley GB 1997 Haemodynamics of pancreatic ischemia in cardiogenic shock. Gastroenterology 113 938-945.

Santoro D, Natali A, Palombo C, Brandi LS, Piatti M, Ghione S \& Ferrannini E 1992 Effects of chronic angiotensin converting enzyme inhibition on glucose tolerance and insulin sensitivity in essential hypertension. Hypertension 20 181-191.

Speth RC, Daubert DL \& Grove KL 1999 Angiotensin II: a reproductive hormone too? Regulatory Peptides 79 25-40.

Stern MP 1995 Diabetes and cardiovascular disease: the common soil hypothesis. Diabetes 44 369-374.

Tahmasebi M, Puddefoot JR, Inwang ER \& Vinson GP 1999 The tissue renin-angiotensin system in human pancreas. Fournal of Endocrinology 161 317-322.

Thomas WG \& Sernia C 1988 Immunocytochemical localization of angiotensinogen in the rat brain. Neuroscience 25 319-341.

Ushio-Fukai M, Alexander RW, Akers M \& Griendling KK 1998 p38 Mitogen-activated protein kinase is a critical component of the redox-sensitive signaling pathways activated by angiotensin II. Role in vascular smooth muscle cell hypertrophy. Fournal of Biological Chemistry 273 15022-15029.

Warnholtz A, Nickenig G, Schultz E, Macharzina R, Brasen JH, Skatchkov M, Heitzer T, Stasch JP, Griendling KK, Harrison DG, Bohm M, Meinertz T \& Munzel T 1999 Increased NADH-oxidase-mediated superoxide production in the early stages of atherosclerosis: evidence for involvement of the renin-angiotensin system. Circulation $992027-2033$.

Wedgewood K \& Reber HA 1986 Acute pancreatitis: the concepts of pathogenesis. In Surgical Diseases of the Pancreas, pp 12-25. Eds J Howard, G Jordan \& HA Reber. Philadelphia: Lea and Febiger.

Whitcomb DC 1999 Acute pancreatitis: mechanisms of cell injury. In Pancreatic Disease, pp 3-13. Eds PG Lankisch \& EP DiMagno. Berlin: Springer Verlag.

Zimmerman BG \& Dunham EW 1997 Tissue reninangiotensin system: a site of drug actions? Annual Review of Pharmacology and Toxicology 37 53-69.

RECEIVED 19 February 2001

ACCEPTED 5 March 2001 